\title{
Nation and Immigration
}

\section{Ali Behdad, University of California, Los Angeles}

A close friend of mine, who happens to be a neuroscientist - well acquainted with all the vicissitudes of our brains_recently told me: 'You know, I always thought you had a highly theoretical and abstract mind, but I now realize that you are really a meat and potato kind of guy!’ Though I was initially hurt by his rather blunt and unsolicited observation, as I thought about it more I began to realize that there was perhaps some truth to what he was saying and that being a 'meat and potato guy' is not so bad after all! I begin by recounting this conversation both to apologize if what I have to say in this article sounds a bit too commonsensical, and to contextualize my seemingly anachronistic return to such 'old-fashioned' concepts as nation and immigration in what appears to be a globalized world populated by 'nomadic subjects'.

Even a cursory glance at the recent works of cultural critics and postcolonial theorists will suffice to confirm that keywords such as nation and immigration are no longer in vogue today, as new concepts such as postnation and diaspora have displaced them in our current intellectual parlance. Encouraged by seemingly radical changes heralded by economic globalization, transnational migration across the globe, and the spread of electronic culture, most cultural and postcolonial theorists have suggested that overmastering and monologic notions of identity and culture associated with a particular nation or ethnicity impair intellectual freedom, suppress creative interaction between members of various communities, and ultimately fail to describe the nuanced and complicated hybrid formations that characterize our global relations today. These critics therefore view the nation form as an obsolete model of community, cultivated only by 
ethnic fundamentalists and oppressive regimes, while considering nationalism a dark, antiquated, and repressive discourse producing only ethnic conflicts and monolithic forms of identification. Roger Rouse, to cite a seminal example of this position, remarks:

We live in a confusing world, a world of crisscrossed economies, intersecting systems of meaning and fragmented identities. Suddenly, the comforting modern imagery of nation-states and national languages, of coherent communities and consistent subjectivities, of dominant centers and distant margins no longer seems adequate (Rouse 1991, 8).

Most cultural critics, like Rouse, have theorized often in a celebratory fashion, tropes of mobility such as exile, travel, displacement, nomadism, and diaspora as keywords to account for contemporary forms of cultural identity. In several of his works, Edward Said, for example, while attentive to the psychological losses and political disenfranchisement that dislocation entails, quoted the words of a thirteenth-century monk, Hugo of Saint Victor, to argue that total exile and absolute refusal to belong is the most complete form of identity and intellectual subjectivity (Said 1984). Distance and alienation, as horrendous as they are to experience, according to him, nonetheless enable critical insight and originality of vision, forcing us to abandon fixed notions of identity as well as eschewing ideologies of mastery and nationalistic attachments. Similarly, Stuart Hall has constantly valorized diaspora identities, describing them as capable of 'constantly producing and reproducing themselves anew, through transformation and difference' (Hall 1990, 235). Like Said, Hall views the decision to live in self-exile, without the security of one's culture, as a redemptive movement, one that mediates a dialogic awareness, thus enabling the creative process of writing and critical thinking. And finally, Homi Bhabha has further claimed that postcolonial people, as deterritorialized subjects, 'displace some of the great metropolitan narratives of progress and law and order, and question the authority and authenticity of those narratives' (Bhabha 1990b, 218). According to Bhabha, diasporas, as exemplary communities of the global world, are necessarily politicized and oppositional, always working collectively against oppressive power relations and cultural hegemony while displacing nationalist forms of identification with their nomadic subjectivities.

I have titled my paper 'nation and immigration' by way of intimating my intellectual alignment with an alternative theoretical position that is critical of celebratory theories of 
postcoloniality. I have in mind here scholars such as Kitty Calavita (Inside the State: The Bracero Program, Immigration, and the INS, 1992), Maxim Silverman (Deconstructing the Nation: Immigration, Racism and Citizenship in Modern France, 1992), William Barbieri (Ethics of Citizenship: Immigration and Group Rights in Germany, 1998), and Paul Gilroy ('There Ain't No Black in the Union Jack': The Cultural Politics of Race and Nation, 1987). In the works of these critics, situated terms (like immigration, citizenship, race, and racism) displace abstract notions (like diaspora, deterritorialization, exile, and hybridity). In what follows, therefore, I wish to offer a critical assessment of the cultural and political implications of postcolonial and cultural critics' abandonment of situated terms like immigration, citizenship, race, state, and their celebratory embracing of such unmoored notions as nomadism, deterritorialization, exile, hybridity, and postnation. On the one hand, I hope to demonstrate that postcolonial critics' valorization of displacement's redemptive power mystifies the oppositional possibilities of hybrid consciousness. On the other, I wish to argue that such theoretical projects fail to both historicize the particularities of postcolonial cultural formations and the importance of the politics of location in describing various manifestations of the global.

In his seminal essay, 'Patriotism and Its Futures', Appadurai posits the concepts of 'postnation' and 'postnational' to describe the cultural and political conditions of global formations today (Appadurai 1993). He uses these terms to elaborate three related implications of globalization as a general phenomenon, transforming cultural, economic, and political relations everywhere in the world. First, he employs these terms to mean 'the [historical] process of moving to a global order in which the nation-state has become obsolete and other formations for allegiance and identity have taken its place'. Second, he has in mind the 'alternative forms for the organization of global traffic in resources, images, and ideas—-forms that either contest the nation-state actively or constitute peaceful alternatives for large-scale political loyalties'. And third, the notion of postnation implies what may be labeled diasporic nationalism, which, encouraged by 'the steady erosion of the capabilities of the nation-state to monopolize loyalty,' are 'largely divorced from territorial states' (169). The example that Appadurai cites to drive these points home is, interestingly, the United States, an enormously wealthy superpower that 
has been able to organize itself around 'a modern political ideology in which pluralism is central to the conduct of democratic life'-a nation where various immigrant communities have been able to manufacture what he calls 'delocalized transnations' that retain special ideological links to a putative place of origin but are otherwise thoroughly diasporic collectivities (173). Insightful though Appadurai's argument is in locating the cultural implications of globalization, his salutary claims about the disappearance of nation-state and the emergence of diaspora communities appear problematic, especially since 9/11, a tragic event that not only ushered a powerful form of patriotism in the United States, but also helped fortify the power of state apparatuses such as FBI, CIA, and the INS, linked and centrally organized now under the rubric of the new Department of Homeland Security. I have discussed the impact of 9/11 elsewhere (Behdad forthcoming), but let me restate here parenthetically a crucial point about the specific context of the United States before I proceed with my discussion of Appadurai's argument. What is remarkable about the hurried passage of the USA Patriotic Act that essentially curtailed certain constitutional rights of citizens after 9/11 was the powerful way in which the figure of the immigrant/foreigner once again provided the differential other through whose threatening presence in the nation a state of emergency was declared, enabling thus the entrenchment of disciplinary apparatuses and surveillance procedures as necessary security measures to protect the democratic polity from the other's terror-apparatuses and surveillance procedures that had already been tested and used at the U.S.-Mexico border long before the tragic events of 9/11 gave the government the perfect rationale to extent them to every port of entry. Not only was a substantial part of the Patriot Act devoted to the enhancement of regulatory immigration procedures that denied foreigners, immigrants, and permanent residents habeas corpus and due judicial review and permitted indefinite detention of those in violation of any immigration status, including such a minor offense as overstaying a visa, but the bill also implicitly depicted the brown-skinned immigrant-Middle Eastern, Southeast Asian, and Latino, among others-as a threat to the democratic nation in an apocalyptic fashion that called for an Armageddon on the part of the state to eradicate the (terrorist) foreigner or immigrant. But, as I suggested above, even before such legislative changes, it was already evident that, although with the emergence of global politics and the spread of free-trade zones, 
the borders of nation-states had become increasingly porous, national governments continued to exercise a great deal of power in planning and shaping the ways in which their countries are globalized. Indeed, international organizations depend on individual state agencies to regulate trade and security, markets and systems of communication.

Now, to return to Appadurai’s argument in the context of my critique of postcolonial theories of postnation and hybridity, I think it is important to note that Appadurai's argument about the disappearance of the nation-state and the emergence of diaspora consciousness holds a mimetic relation with anti-colonial discourse on nation and nationalism. As one reads Appadurai’s compelling argument about the disappearing of nation-state, the specter of Fanon appears above and beneath every sentence-Fanon who first described the predicaments of national consciousness in the colony in his seminal book, The Wretched of the Earth (1963). Describing nationalism as an 'empty shell', Fanon cogently observed that 'the battle against colonialism [and oppression] does not run straight away along the lines of nationalism’ (148). As a cosmopolitan intellectual, he considered internationalism as the goal of anti-colonial movement, arguing that at the heart of liberation movement an 'international consciousness lives and grows' (248). And yet, in the following chapter on national culture, Fanon claimed that 'every culture is first and foremost national', and that the demand for nationhood, the desire for national culture, and the process of decolonization are intertwined (216). The task of the colonial intellectual, then, was to help produce an 'authentic national consciousness, freed from the psychological and ideological forces of colonialism' - a consciousness that involved a movement away from what he labeled 'Western culture' toward a popular and democratic form of nationhood that empowered every social strata.

What we encounter in the discourses of postnationalism and diaspora today is a similar ideological ambivalence toward what constitutes national consciousness and belonging. Whether we read Said, Bhabha or Appadurai, we notice the paired critique of nationalism and celebration of a more cosmopolitan, imagined community_for Said, it is the calling for a Palestinian nation that haunts his celebration of exile as a metaphor of ideal subjectivity; for Bhabha, it is the 'scattering of the people that in other times and other 
places, in the nations of others, becomes a time of gathering' (Bhabha 1990a, 291); and for Appadurai it is the delocalized transnation that is celebrated against the white nation. What are we to make of these contradictory articulations of the nation form? How are we to go beyond the problematic binary of good nationalism vs. bad nationalism implied in this critical debate?

A starting point to address these questions is to unpack the relation between state and nation and explore their roles in the global flow of people, capital, and commodities that characterize our contemporary world. What is striking about critiques of nation and nationalism by cultural and postcolonial theorists is the absence of any substantial discussion of the state, especially problematic because the nation and state are often linked - that is, in the nation-state-if not fully equated. Often reduced to a repressive apparatus, the notion of state is considered passé in today’s Western academy, associated with an outdated Marxist paradigm that limited its function to maintaining class domination. But I want to suggest a return to this key term and question the extent to which the rhetoric of globalization has obscured the important role states and governments play in transnational relations of power. Indeed, state apparatuses continue to retain, if not exclusive, tremendous power over deployment of force as well as the authority to regulate how transnational corporations invest their resources and engage in business transactions. We should ask, therefore, what functions do states, as agencies of representation, perform in the broader system of international regulation? Do global agencies and transnational corporations really undermine the sovereignty of national governments? Have states become the local agents of corporate interests? Or, does the fact of their being ultimately answerable to their citizens make them the local shields against global capitalism? Can states re-create a sense of national identity in response to the political and economic constraints of globalization? Or, do state apparatuses mobilize the idea of the nation to enable economic interests of transnational corporations? I raise these questions both to underscore the problematic tendency among postcolonial and cultural critics to overlook the function of states and their apparatuses in how global networks and transnational relations are formed and to offer new areas of inquiry in unpacking and understanding the impact of global interconnectedness. 
But the overlooking of the roles of nation and state in recent theories of diaspora and postnationalism seems also problematic given the speed with which new nations and nationalism are actually emerging today, the peculiar propensity for and the intensity of border fortification in spite of the global flow of people and commodities across them, and the forging of new partnerships between certain states and the global capital market. I want to suggest that while national borders may no longer impede most of the international trade and other global economic transactions, they do nonetheless matter greatly when it comes to human subjects whose movements are carefully regulated. I have shown elsewhere that in the past twenty years the principle of governmentality in the United States has actually been solidified, as demonstrated, for example, by the expansion of the prison industry and the proliferation of the technologies of border control at the US-Mexico border (Behdad 1998). Similarly, the integration of Europe in the form of a union has also meant tougher restrictions on the movement of people from the Middle East, Africa, and most of Asia to Europe.

Moreover, in spite of the increase in global cultural contacts, nationalist sentiments persist throughout the world and states continue to exert a great deal of power as to how a national community is globalized. On the one hand, as R. Radhakrishnan points out:

neither the deracinating multi- or inter-national spread of capitalism nor the Marxist theoretical assimilation of the national question within an internationalist communism has been able to do away with the urgencies of the imagined communities of nationalism (Radhakrishnan 1992, 83).

Nationalism and state apparatuses remain powerful everywhere, in Iran and the United States, in Serbia as well as France. And, without romanticizing the role of states and nationalism, one may add that in an era of foot-loose capitalism, certain nationalist sentiments or state forms of sovereignty may in fact prove useful in countering the lack of accountability on the part of giant transnational corporations. On the other hand, even the social scientists who argue that 'the contemporary globalization of politics is transforming the very foundations of world order by reconstituting traditional forms of sovereign statehood and reordering international political relations' have to acknowledge that the concept of state 'sovereignty has by no means been rendered redundant' and that 
'political community continue to be shaped by the territorial reach of state sovereignty' (Held et al 1999, 85-86). In other words, neither the internationalization of politics, nor the globalization of capital implies the disappearance of national form or state government. Quite the contrary, globalization has actually reinforced their role as arbitrators in international processes. There remain indeed many questions to be answered yet about the problem of the nation-state and its ideological apparatuses. How, for example, is the nation-state re-imagined in our globalized world? What roles do states play in the particular ways in which globalization is embraced and practiced in different locations? How are we to account for the rise of nationalist, religious, and ethnic fervor in a world that has become increasingly more transnational? What are the ways in which the formal universality of nationalism as a socio-political concept can be understood in the context of the irremediable particularity of nationalism's concrete manifestations? And finally, how can we simultaneously critique the regressive tendencies of nationalism in Bosnia and Rwanda while advocating, say, a Palestinian or Kurdish nation?

Saskia Sassen in her illuminating essay 'Spatialities and Temporalities of the Global: Elements for a Theorization' cogently suggests that globalization 'persists as a partial condition' by which she means that there is significant overlap and interaction between the global and the national (Sassen 2000, 215). She writes, 'Each sphere, global and national, describes a spatio-temporal order with considerable internal differentiation and growing mutual imbrications with the other' (216). One direction, she seems to suggest, is not to forget the nation in our postnational consciousness, but to study instead the 'dynamics of interaction between the global and the national', a dynamic that sheds light on the 'incipient and partial denationalization of domains once understood and/or constructed as national' (216). What the more nuanced discussions of globalization such as Sassen's make evident is that the uneven flow between nationalism and globalization is fundamentally context-dependent, and that while transnational circuits are appearing throughout the world, their formations are always socio-historically contingent and culturally specific. Indeed, the strategic nature of economic globalization, as Sassen cogently argues, suggests that 'most global processes materialize in national territories 
and do so to a considerable extent through national institutional arrangements, from legislative actions to corporate agenda’ (228).

The second issue I wish to raise with regard to Appadurai's exemplary description of the global is the question of diaspora and its liberating potentials. Diaspora is at once the cause and effect of postnational consciousness and as such it occupies a central role in the way new identities are imagined in the global village, according to him. Appadurai, like most postcolonial critics, views the presence of diasporic communities in the United States in salutary terms, considering them essential in fashioning a new 'postnational politics' that would ultimately resolve 'the tension between the centripetal pull of Americanness and the centrifugal push of diasporic diversity in American life' (Appadurai 1993, 173). The emergence of delocalized transnations, he argues, is forcing American society to 'confront the needs of pluralism and of immigration, to construct a society around diasporic diversity’ (173). I take issue with Appadurai’s claim for several reasons. To begin, as a specific claim about the new global order, it overlooks the fact that the United States has always constructed its national identity around diversity and immigration. Indeed, beginning with J. Hector St. John de Crèvecoeur's invocation of America as ‘every person's country' in 1782, through the celebration of the country as a 'nation of many nations' in the poetry of Walt Whitman in the nineteenth century, to John F. Kennedy's portrayal of the United States as a 'nation of immigrants' in the twentieth century, the official archive of the nation is replete with examples of this founding myth that defines immigration as the cornerstone of national identity. But what Appadurai fails to further observe is that such a construction of identity is a forgetful articulation that suppresses historical knowledge about the economics of immigration, while producing a pseudo-historical consciousness about what it means to be an American. I have elaborated elsewhere (Behdad, 2005) the productive function of the myth of immigrant America, but it is worth pointing out in passing that the benign myth of immigrant America is frequently called upon to shore up a sense of national pride and to enable cultural renewal. Such a project of national identification remains potent because it disavows the ways in which the formation of American polity was achieved through the violent conquest of Native Americans, the brutal exploitation of enslaved Africans, and 
the colonialist annexations of French and Mexican territories, not to mention the fact that the narrative of immigrant America helps us turn a blind to the nation's long history of xenophobia and to the disciplining and criminalizing of aliens today.

Moreover, on an empirical level, it is not evident that geographical displacement necessarily leads in most cases to any originality of political vision, to the breaking of intellectual and cultural barriers, and to solidarity in opposing hegemonic power of the majority, as most postcolonial and cultural theorists tend to suggest. For, even the most superficial acquaintance with the ethnic politics of a city like Los Angeles reveals how stratified and conflicted Third World-origin and minority communities are in this city. Not only are there fundamental cultural and economic differences among various diaspora communities, but also these differences have often sowed mutual hostilities across immigrant and minority communities, as the Los Angeles riots in 1992 painfully demonstrated. The 'postnational' communities in Los Angeles are often more chauvinistic and nostalgic towards their countries of origins than the citizens of those nations, a fact that is sociologically evident in the rise of ethnic enclaves throughout the city and their nostalgic re-invention of certain arcane traditions. In many cases, the sense of loss and disenfranchisement among many immigrant communities has led to a new form of tribalism characterized by antagonism and racial superiority toward other minorities. As James Clifford points out, 'Indeed, some of the most violent articulations of purity and racial exclusivism come from diaspora populations' (Clifford 1997, 251). In short, it is not clear that 'delocalized transnations' are free from the chauvinism of nationalism or the forces of state apparatuses, as Appadurai seems to suggest, nor is it evident that they necessarily constitute oppositional alternatives to the hegemonic power of the majority by displacing 'the great metropolitan narratives of progress, law, and order', as Bhabha claims (Appadurai 1996, 169; Bhabha 1990b, 218).

In addition, it is important to note that, as Edouard Glissant has cogently argued, 'The permutations of cultural contact change more quickly than any one theory could account for. No theory of cultural contact is [thus] conducive to generalization' (Glissant 1989, 19). Hence the importance of the local and the impossibility of a generalizing notion of 
postcolonial or postnational subjectivity, for transnational forms are always interpolated by the politics of location, and as such their manifestations can be quite varied, and always over-determined. There are, for example, obvious differences between the experiences of various immigrant communities in the United States — for instance, while some communities, such as Armenians in Glendale, California, have been able to maintain a sense of collectivity and cultural particularity across their national backgrounds, Caribbean immigrants in New York City have fashioned a creolized identity with blacks and Latinos, an identity that is less ethnically rigid and more culturally fluid. In addition, there are also radical permutations even within a single immigrant community, permutations that, again, are over-determined by class, gender, religion, and language. Such differences within and across immigrant communities demand an understanding of interculturality that is attentive to the specificity of their historical formations and geographical locations.

My aim in raising the issue of diasporic exclusivism and its local interpolation is not to pose a binary relation between the symbolic and the real. Nor is it my aim to claim nationalist sentiment as an antidote to global disempowerment. Rather, my hope is to draw attention to the discrepancy between celebratory explorations of diasporic consciousness by academics, writers, and artists and the complex and over-determined itineraries of many immigrants caught in the tailspin of a globalization that has made them immigrate to the West in hopes of upward economic mobility and political freedom. This discrepancy is symptomatic of the difference between what the political theorist John Armstrong calls ‘mobilized and proletarian diasporas’ (Armstrong 1976). Armstrong acknowledges the vagueness of the term 'diaspora' to describe 'any ethnic collectivity which lacks a territorial base within a given polity’. But he attempts to make this term more useful by introducing what I consider to be a very helpful, albeit insufficient, distinction between the proletarian class of diasporas who are 'a disadvantaged product of modernized polities' (for example, Mexican farm and service workers in Southern California) and the mobilized class, defined as 'an ethnic group which does not have a general status advantage, yet which enjoys many material and cultural advantages compared to other groups in the multiethnic polity’ (for example, 
Iranians in Southern California or Indians in Northern California) (393). Armstrong raises not only the issue of social class or even symbolic capital here, but he also discusses a broad range of other factors such as religion, language, labor, cultural myth, networks of family and personal relationships to schematize the critical differences that exist between various communities of immigrants. Obviously, no diasporic community fits neatly into these categories, because immigrants occupy a plurality of social and economic positions, but this sort of distinction is critically necessary, because it calls into question the unmoored metaphors of border-crossing, nomadism, and hybridity so prevalent among postcolonial intellectuals and cultural critics. The kind of distinction Armstrong introduces is useful in helping us differentiate various trajectories of displacement and become attentive to the historical taintedness of tropes of mobility that are so fashionable in intellectual circles today.

Moreover, Armstrong's distinction between mobilized and proletariat diasporas is helpful in understanding why émigré writers and intellectuals from the ex-European colonies as privileged diasporas_-privileged by virtue of access to discourse and representationview displacement in celebratory terms while representing the everyday struggles of ordinary immigrants in Western metropolises in their aesthetic and critical discourses, representations that, as Gayatri Spivak has cogently shown, are often marked by a double contradiction: a misrepresentation of alternative histories of colonialism and a misconception of the neo-colonial condition (Spivak 1989).

To ignore the crucial economic and cultural differences among immigrant communities by generalizing and labeling them all 'postnational others' marginalized by the white nation-state or Western narrative of progress, as Appadurai and Bhabha do in their works, is not only intellectually problematic, but also politically dangerous. I say intellectually problematic because such claims tend to assume a binary relationship between center and periphery, power and opposition, hegemony and resistance, and nationalism and exile in describing the predicament of geographical displacement, and as such fail to address the complex and over-determined configurations of transnational relations of power that force or enable migration. And I say such claims are politically dangerous because they 
risk inflating the privileged itineraries of certain postcolonial intellectuals and expatriate professionals with those of disenfranchised immigrants and displaced refugees, a conflation that participates in the mobilization of the myth of immigrant America to shore up patriotism and enable cultural renewal.

Mahatma Gandhi was once asked what he thought of Western civilization and he responded: 'It would be a good idea!' Gandhi’s insightfully sarcastic response captures this paper's position with regard to tropes of mobility and discourses of transnationalism. The popular rhetoric of postnationalism and diaspora suggest that the world is becoming a better place to live through an intensification of economic interdependence, technological interconnectedness, and cultural hybridization. The demise of state power, according to the boosters of globalization, has led to a positive diffusion of authority, while technological advances have enabled a more mobile and pluralistic sense of cultural and political identity. These would obviously be salutary developments were it not for the fact that they are available only to a tiny and privileged minority. As Pico Iyer insightfully observes:

one of the most troubling features of the globalization we celebrate is that the so-called linking of the planet has, in fact, intensified the distance between people: the richest 358 people in the world, by UN calculations, have a financial worth as great as that of 2.3 billion others, and even in the United States, the prosperous home of egalitarianism, the most wired man in the land (Bill Gates) has a net worth larger than that of 40 percent of the country's households, or perhaps 100 million of his compatriots combined (Iyer 2000, 25-26).

If I espouse the skeptical position in these postcolonial debates it is not to undermine the advantages of cultural, economic and political interconnectedness, but to draw attention to how the boosters of transnationalism and diaspora have failed to address the contingent and uneven nature of global flow. What seem urgent now are not more paeans to the global ideal, but a willingness to confront the challenges that stand in the way of its realization. Counter-intuitively perhaps, a global future demands a present engagement with the enduring issue of unequal and uneven development.

To conclude, what I have been obliquely attempting here has been to suggest that a critical form of postcolonial discourse can offer a historical corrective to the celebratory theories of diaspora and postnationalism. I think cultural theories of transnationalism and 
globalization have been blinkered by the misty notion of 'time/space compression', coined by David Harvey as a postmodern phenomenon to describe the ways in which new technologies of communication have shrunk geographical and temporal distance, enabling a condition of instantaneity in human interactions as well as the possibility of transculturation and hybridity (Harvey 1989). The speed and widening of global interconnectedness seem to have rendered history and geography obsolete, as the transnational flows of people and commodities, ideas and images, capital and information are claimed to dismantle such temporal and spatial barriers as nation and state. This popular view of our contemporary condition not only dissimulates the spatial segregation that characterizes the current form of globalization but it also overlooks the (neo-) colonial dimensions of its complex genealogy. A historically informed engagement with the unequal geography of transnationalism can constitute a critical step in a new direction for postcolonial theorists. In other words, instead of 'going beyond' what postcolonialism has already theorized about European forms of imperialism by jumping on the bandwagon of globalization discourse, we may deploy the historical and political knowledge that (post)colonial works have already produced to explore the unequal geography of globalization and its historical links with European colonialism and the process of decolonization.

Economists have singled out two historical periods, 1870-1939 and 1950-1973, as central to the rise of global order: while in the first period 'markets for key goods began to acquire a global dimension', during the second period, labeled the 'golden age', 'trade volumes grew at 5.8 per cent per annum, ... [and] world output grew at an unprecedented rate of 3.9 per cent per annum' (Held et al 1999, 163-164). What has been overlooked by economists, however, is the role of European colonialism and de-colonization in the rise of global order, neither acknowledging nor exploring the fact that these periods coincided with the height of European colonialism and its dismantling, respectively. Postcolonial discourse, I think, is well positioned to map the colonial contexts of global flows to discern the unequal geography of our global condition. In particular, postcolonial historiography can provide a critical genealogy to explicate the political shift from European colonialism to American imperialism. What are the conditions, we may ask for 
example, that enabled the global spread of imperialism after the spectacular phenomenon of de-colonization? What cultural attitudes, political practices, and economic strategies from the colonial period continue to persist today? Why have ex-colonized nations failed to reap the benefits of global trade? There are certainly no easy answers to these questions, but to grapple with the issues they raise may provide a springboard, if not a framework, towards a postcolonial genealogy of globalization.

\section{Reference List}

Appadurai, A. 1993, 'Patriotism and its Futures', Public Cultures, vol. 5, no. 3, 411-429, reprinted in Appadurai, A. 1996, Modernity at Large: Cultural Dimensions of Globalization, University of Minnesota Press, 158-177. 1996, Modernity at Large: Cultural Dimensions of Globalization, University of Minnesota Press, Minneapolis, 169

Armstrong, J. 1976, 'Mobilized and Proletarian Diasporas', The American Political Science Review, vol. 70, no. 2, 393-408.

Barbieri, W. 1998, Ethics of Citizenship: Immigration and Group Rights in Germany, Duke University Press Durham, NC.

Behdad, A. Forthcoming, A Forgetful Nation: On Immigration and Cultural Identity in the United States, Duke University Press, Durham NC. 1998, 'INS and Outs: Producing Delinquency at the Border', Aztlan: A Journal of Chicano Studies, vol. 23, no. 1, 103-14. 2005, A Forgetful Nation: On Immigration and Cultural Identity in the United States, Duke University Press, Durham NC.

Bhabha, H. 1990a, 'DissemiNation: time, narrative and the margins of the modern nation', in Nation and Narration, ed. H. Bhabha, Routledge, New York, 291-322. 1990b, 'The Third Space', in Identity, Community, Culture, Difference, ed. J. Rutherford, Lawrence and Wishart, London, 207-221

Calavita, K. 1992, Inside the State: The Bracero Program, Immigration and the INS, reference details?

Clifford, J. 1997, Routes: Travel and Translation in the Late Twentieth Century, Harvard University Press, Cambridge, 1997.

Fanon, F. 1963, The Wretched of the Earth, trans. C. Farrington, Ballantine Books, New York.

Gilroy, P. 1987, 'There Ain't No Black in the Union Jack': The Cultural Politics of Race and Nation, Hutchinson, London.

Glissant, E. 1989, Caribbean Discourse: Selected Essays, trans. M. Dash, University of Virgina Press, Charlottesville.

Held, D. et al 1999, Global transformations : politics, economics and culture, Polity Press, Cambridge

Hall, S. 1990, 'Cultural Identity and Diaspora', in Identity, Community, Culture, Difference, ed. J. Rutherford, Lawrence and Wishart, London, 222-37

Harvey, D. 1989, The Search for Postmodernity, Blackwell, Oxford. 
Iyer, P. 2000, The Global Soul: Jet Lag, Shopping Malls, and the Search for Home, Vintage Books, New York.

Radhakrishnan, R. 1992, 'Nationalism, Gender and the Narrative of Identity', in Nationalisms \& Sexualities, ed. A. Parker, M. Russo, D. Sommer and P. Yaeger, Routledge, New York, 77-95.

Rouse, R. 1991, 'Mexican Migration and the Social Space of Postmodernism', Diaspora: A Journal of Transnational Studies, vol. 1, no. 1, (Spring), 8-23.

Said, E. 1984, 'Reflections on Exile, Granta, vol. 13, 159-172.

Sassen, S. 2000, 'Spatialities and Temporalities of the Global: Elements for a Theorization', Public Culture, vol. 12, no. 1, 215-32.

Silverman, M. 1992, Deconstructing the Nation: Immigration, Racism and Citizenship in Modern France, Routledge, London.

Spivak, G. 1989, 'Who Claims Alterity?', in Remaking History, ed. B. Kruger and P. Mariani, Bay Press, Seattle, 269-292. 